\title{
Erik Damgaard
}

\section{Demokrati og politisk udvikling}

Doktorafhandlinger indleveres som bekendt i forskellige former. I det aktuelle tilfælde er der tale om to publicerede engelsksprogede bøger og en artikel (ligeledes på engelsk) foruden, som reglerne foreskriver for et sådant tilfælde, en sammenfattende redegørelse på dansk.

Indholdsmæssigt kan disse arbejder vel siges at befinde sig i det interessante grænseområde mellem de to politologiske discipliner, vi i daglig tale på Institut for Statskundskab kalder henholdsvis international politik og komparativ politik. Man kunne måske også sige, at de alle falder ind under, hvad Instituttet officielt benævner almen og sammenlignende statskundskab.

Mere interessant end faglige grænsediskussioner er imidlertid det dobbelte spørgsmål: Hvad er i grunden de overordnede problemstillinger i de nævnte arbejder, og hvordan hænger de sammen? Det eller de spørgsmål vil jeg gerne først se lidt på. Derefter er der grund til kort at betragte nogle af de helt centrale begreber i analyserne. Et tredje punkt vedrører de mere metodiske aspekter. Et fjerde interessant punkt er nogle af undersøgelsesresultaterne. Endelig er der så analysernes implikationer $\mathrm{i}$ forskellige henseender, empirisk såvel som normativt.

Det lyder måske forholdsvis overkommeligt at diskutere disse fem punkter. Men helt så enkelt er det nu ikke. Under arbejdet med præses' afhandlinger, der alle oplyses at være skrevet i perioden 1987-1992, gik det nemlig op for mig, at jeg faktisk skulle skyde på det, man på engelsk kalder "a moving target". Det kan være svært at ramme noget, som hele tiden bevæger sig. Det ved enhver jæger, men jeg skal dog forsøge.

\section{Problemstillinger}

Hvad nu først problemstillingerne angår, får vi i den sammenfattende redegørelse straks at vide, at det fælles tema for arbejderne er "demokratiets konsekvenser for den tredje verden, specielt konsekvenserne for økonomisk udvikling”. Det er ganske korrekt. Betragter man således den første bog (Democracy, Dictatorship and Development), kunne man sige, at den overordnede problemstilling er forskellige styreformers konsekvenser for økonomisk udvikling, idet der på den ene side sondres mellem demokratisk og autoritært styre, og på den anden side mellem forskellige aspekter af økonomisk udvikling, nemlig vækst og velfærd.

På dette abstrakte plan er det hele såre enkelt, hvilket fremgår af følgende:

\begin{tabular}{ll}
\hline STYREFORMER & $\longrightarrow$ \\
\hline - demokratiske & OKONOMISK UDVIKLING \\
- autoritære & - vækst \\
- velfærd
\end{tabular}




\section{Erik Damgaard}

\section{Demokrati og politisk udvikling}

Doktorafhandlinger indleveres som bekendt i forskellige former. I det aktuelle tilfælde er der tale om to publicerede engelsksprogede bøger og en artikel (ligeledes på engelsk) foruden, som reglerne foreskriver for et sådant tilfælde, en sammenfattende redegørelse på dansk.

Indholdsmæssigt kan disse arbejder vel siges at befinde sig i det interessante grænseområde mellem de to politologiske discipliner, vi i daglig tale på Institut for Statskundskab kalder henholdsvis international politik og komparativ politik. Man kunne måske også sige, at de alle falder ind under, hvad Instituttet officielt benævner almen og sammenlignende statskundskab.

Mere interessant end faglige grænsediskussioner er imidlertid det dobbelte spørgsmål: Hvad er i grunden de overordnede problemstillinger i de nævnte arbejder, og hvordan hænger de sammen? Det eller de spørgsmål vil jeg gerne først se lidt på. Derefter er der grund til kort at betragte nogle af de helt centrale begreber i analyserne. Et tredje punkt vedrører de mere metodiske aspekter. Et fjerde interessant punkt er nogle af undersøgelsesresultaterne. Endelig er der så analysernes implikationer $\mathrm{i}$ forskellige henseender, empirisk såvel som normativt.

Det lyder måske forholdsvis overkommeligt at diskutere disse fem punkter. Men helt så enkelt er det nu ikke. Under arbejdet med præses' afhandlinger, der alle oplyses at være skrevet i perioden 1987-1992, gik det nemlig op for mig, at jeg faktisk skulle skyde på det, man på engelsk kalder "a moving target". Det kan være svært at ramme noget, som hele tiden bevæger sig. Det ved enhver jæger, men jeg skal dog forsøge.

\section{Problemstillinger}

Hvad nu først problemstillingerne angår, får vi i den sammenfattende redegørelse straks at vide, at det fælles tema for arbejderne er "demokratiets konsekvenser for den tredje verden, specielt konsekvenserne for økonomisk udvikling”. Det er ganske korrekt. Betragter man således den første bog (Democracy, Dictatorship and Development), kunne man sige, at den overordnede problemstilling er forskellige styreformers konsekvenser for økonomisk udvikling, idet der på den ene side sondres mellem demokratisk og autoritært styre, og på den anden side mellem forskellige aspekter af økonomisk udvikling, nemlig vækst og velfærd.

På dette abstrakte plan er det hele såre enkelt, hvilket fremgår af følgende:

\begin{tabular}{ll}
\hline STYREFORMER & $\longrightarrow$ \\
\hline - demokratiske & OKONOMISK UDVIKLING \\
- autoritære & - vækst \\
- velfærd
\end{tabular}


Hvad denne overordnede problemstilling indebærer, får man bedre forstand på, hvis man betragter de hypoteser og generelle spørgsmål, der formuleres og stilles til nærmere afprøvning og undersøgelse. I Democracy, Dictatorship and Development præsenteres, efter en rimeligt omfattende gennemgang af synspunkterne på området, seks hypoteser eller hovedspørgsmål til nærmere undersøgelse.

Der er to udgangshypoteser: Den ene siger, at autoritære regimer er bedre til at fremme okonomisk vækst end demokratiske styreformer, fordi de bedre kan holde forbruget nede til fordel for vækstfremmende investeringer. Autoritære regimer har altså størst økonomisk-politisk styringskapacitet, kan man sige.

Den anden udgangshypotese hævder, at demokratiske regimer, $i$ det mindste på kort sigt, er bedre til at fremme velfærd end autoritære styreformer, fordi de folkevalgte er nødt til at lytte til vælgernes ønsker. Man kan sige, at demokratiske regimer er mere repræsentative, responsive eller lydhøre end de autoritære.

Disse to udgangshypoteser illustrerer ganske godt det fundamentale dilemma, al politik teoretisk set drejer sig om: Styring versus repræsentation, ledelse versus deltagelse, styringskapacitet versus folkelig participation, eller hvilket ordpar man nu måtte foretrække.

Men allerede i udgangspunktet er præses klar over, at forholdene i virkelighedens verden kan være mere komplicerede. Således indfører han en tredje hypotese, der bygger på, at autoritære regimer er forskellige. Den "bedste" form for autoritært styre (hvis man da som demokrat kan sige noget sådant, da autoritarianisme demokratisk set jo principielt er af det onde) er det såkaldt autoritære udviklingsregime, fordi det uden de helt store menneskelige omkostninger kan sikre både økonomisk vækst og velstand for den brede befolkning. De såkaldte autoritære berigelsesregimer kan hverken det ene eller det andet, medens de såkaldte autoritære vækstregimer nok kan skabe vækst, men ikke velfærd.

Denne første bog rummer desuden tre andre og mere åbne spørgsmål til undersøgelse (p. 33f). Et spørgsmål er, om den optimale løsning for u-lande kunne være et autoritært styre i en første fase, efterfulgt af et mere demokratisk system i den efterfølgende fase. Præses understreger heldigvis, at analyser af økonomisk udvikling aldrig bør forbise, at demokratiske systemer har en egenværdi, der ikke kan prisfastsættes på et økonomisk marked. Endelig nævner han, at der ud over styreformen er en lang række faktorer, som influerer på økonomisk udvikling (for eksempel p. 29).

I præsentationen af problemstilling og analyseoplæg er præses selvsagt optaget af demokratierne, men de autoritære styreformer synes ikke desto mindre at dominere billedet på en nok så markant måde (for eksempel p. 17, jf. p. 176f). Lad mig udvikle denne betragtning lidt mere, før jeg beder om en første kommentar fra præses.

Jeg nævnte de to udgangshypoteser for et øjeblik siden og føjede til, at præses tillige sondrer mellem tre slags autoritære styreformer. De tre autori- 
tære typer er ikke defineret ved benyttelse af institutionelle karakteristika, som hovedsondringen mellem demokrati og diktatur ellers hviler på, men ved den politik, der faktisk føres i autoritære regimer. I figuren kan det illustreres således:

\section{AUTORITAERE STYREFORMER}

- vækstregime

- berigelsesregime

- udviklingsregime

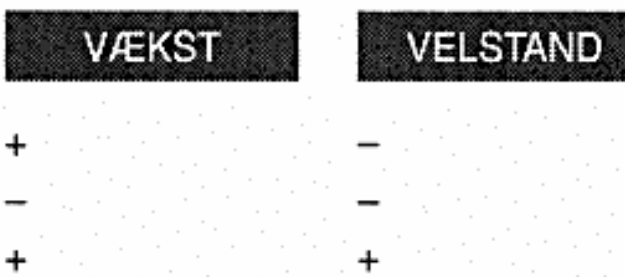

Figuren afspejler for mig at se dels en påstand om, at autoritære regimer kan føre politik med vidt forskellige konsekvenser, og dels at eksempler herpå kan findes rundt omkring i den tredje verden. Præses mener selv, at Kina og Taiwan er eksempler på autoritære udviklingsregimer, og giver desuden eksempler på de øvrige to former, som i øvrigt ikke analyseres nærmere i den første afhandling.

Jeg har nu et par spørgsmål vedrørende symmetrien i bogen om "Demokrati, diktatur og udvikling".

Først vil jeg gerne vide, om der ikke findes autoritære regimer, som ikke kan skabe vækst, men nok velfærd? Er det måske en kombination, der (jeg havde nær sagt per definition) er forbeholdt demokratierne, jf. at demokratiske Costa Rica falder i denne økonomiske udviklingskategori?

Jeg vil gerne straks formulere mit andet spørgsmål til præses i fortsættelse heraf, da det hænger sammen med det første: Burde man ikke differentiere mellem demokratierne på samme måde som mellem de autoritære regimer? Logisk set kunne det lade sig gøre, men er der empirisk anskuet måske ikke grund dertil? Alligevel spørger jeg: Findes der ikke, hvad man kunne kalde demokratiske vækstregimer, demokratiske berigelsesregimer og demokratiske udviklingsregimer - foruden, havde jeg nær sagt, demokratiske demokratier i almindelighed?

Jeg ved godt, at mit "moving target" fremsætter synspunkter af en vis relevans i det andet hovedværk, men dem vil jeg gerne vente lidt med at diskutere.

Denne diskussion leder naturligt frem til spørgsmålet om problemstillingen $i$ den anden bog (Democracy and Democratization). Bogens erklærede formål er at undersøge de senere års udbredte (men vel også noget naive) forventninger om, at indførelse af en demokratisk styreform ikke blot vil fremme frihed og menneskerettigheder, men også føre til hurtig økonomisk udvikling i form af vækst og velfærd såvel som fredeligt samarbejde mellem landene og gensidig forståelse $\mathrm{i}$ internationale relationer.

Bogens overordnede tese er, at de igangværende demokratiseringsprocesser rummer et stort dilemma. På den ene side må det konstateres, at der faktisk er sket store demokratiske fremskridt rundt omkring i den tredje verden, på den anden side er der grund til at sætte alvorlige spørgsmålstegn ved, om demokratiseringen kan leve op til de nævnte store forventninger, som mange måske lidt 
naivt har stillet til konsekvenser af forfatningsændringer i demokratisk retning.

Forskellige kapitler $\mathrm{i}$ bogen analyserer diverse aspekter af dette dilemma med udgangspunkt i fire teser, der ikke skal testes i nogen stringent forstand, men blot bekræftes af den foreliggende empiri, hvad de da også bliver. De fire bekræftede teser påstår,

- at de nye demokratier kun delvist lever op til demokratiske krav (de er, hvad præses kalder "restricted democracies"),

- at de som regel er skrøbelige og ukonsoliderede (de er, hvad præses benævner "frail, unconsolidated democracies"),

- at de lider under voldsomme økonomiske og sociale problemer (de er, som det hedder "democracies plagued by acute social and economic problems"), og

- at de endelig er ledsaget af en stigende folkelig mobilisering og organisering, der vanskeliggør tilbagevenden til autoritært styre, hvilket kan ses som en positiv modvægt til al dårligdommen.

Til disse fire teser føjes så, lidt "uden for nummer" om jeg så må sige, et femte synspunkt om, at man ikke uden videre skal regne med, at de nye demokratier $i$ den tredje verden vil blive inkorporeret $i$ en "global fredsunion", som det hedder med en kantiansk formulering.

Alle disse teser eller synspunkter er relevante og interessante. Forbindelsen til den første bogs problematik etableres især, men ikke udelukkende, gennem analysen $\mathrm{i}$ kapitel 3 af demokratiets konsekvenser for økonomisk vækst og velfærd.

Præses bygger her videre på erfaringerne fra den forste bog, herunder sondringen mellem de tre typer autoritære styreformer. Nyt er imidlertid en sondring mellem to hovedformer for demokrati i relation til mulighederne for okonomisk udvikling. De benævnes henholdsvis elite- og massedominerede demokratier. Både Indien og Costa Rica er elitedominerede, hvorfor der ifølge præses trods alt er grænser for udviklingsmulighederne. Chile var under Salvador Allende (1970-73) et eksempel på et massedomineret demokrati, hvis reformforsøg dog ulykkeligvist blev knust af Pinochets militærkup. Præses fremholder dog, at der findes en gylden middelvej, som muliggør, at forholdsvis stabilt demokrati og økonomisk fremgang kan gå hånd $\mathrm{i}$ hånd. De skandinaviske velfærdsdemokratier nævnes som eksempler herpå, om end de vel aldrig har været kaldt udviklingslande i moderne forstand.

I illustrationen svarer hovedsondringen imidlertid til, at vi underopdeler demokratiske systemer som vist nedenfor, og derefter spørger til de respektive konsekvenser i henseende til økonomisk udvikling. Hvordan forestiller præses sig mon konsekvenserne af de tre demokratiske systemers effekt på økonomisk vækst og velstand, jf. illustrationen:

DEMOKRATISKE STYREFORMER

- elitebaserede (Indien, Costa Rica)

- massebaserede

- mellemform

\section{VFEKST}

$-(?)$

$+$
VELSTAND

\section{$+$}


Altså, hvordan er sammenhængen mellem elite- og massebaseret demokrati på den ene side og de forskellige kombinationer af vækst- og velstandsresultater på den anden side? Kan vi måske håbe på, at mere eller mindre massebaserede demokratier kan skabe både vækst og velstand?

Herefter vil jeg gerne vide lidt mere om de begreber, der knytter sig til autoritært styre og demokratisk styre. Hvorfor sondrer præses på én måde mellem de autoritære regimer og på en anden måde mellem de demokratiske systemer i den tredje verden? Jeg går ud fra, at alle autoritære former per definition er elitedominerede, selv om de åbenbart kan føre en vidt forskellig politik. Eller kan de autoritære former også være massebaserede, som tidligere nazistiske og fascistiske regimer i den første verden vel har været? Demokratierne kan åbenbart være begge dele, så måske er sondringen mellem elite- eller massebasis $\mathrm{i}$ virkeligheden den grundlæggende i forhold til sondringen mellem demokratisk og autoritært styre?

Nyt i denne anden bog i forhold til den første er altså, hvad problemstilling angår, en større bevidsthed om demokratiets variationer i praksis. Jeg mener at finde endnu et nyt træk i den nyeste bog, nemlig en større opmærksomhed over for de sider af demokratiet, som ikke umiddelbart har noget med økonomisk udvikling at gøre, nemlig menneskerettigheder, som demokratiet per definition beskytter. Det mener præses vist også, men han finder dog, at mange demokratier overtræder nogle rettigheder (p. 88), hvilket jeg skal vende tilbage til om et øjeblik.

Før jeg kommer til mit andet hovedpunkt, de centrale begreber i analyserne, vil jeg kort omtale konferencepapiret, Democracy and the Developmental State, for så vidt angår problemstillingen i forhold til de to omtalte bøger.

Paperet beskæftiger sig også med sammenhængen mellem styreformer og okonomisk udvikling. Men præses, "the moving target", har her fundet det nødvendigt at indføre begrebet "statens styrke" $i$ analysen, $i$ øvrigt en idé, der allerede lanceres $i$ den første bogs afsluttende refleksioner. Begrundelsen for inddragelse af dette aspekt er, at styreformen kan have konsekvenser for statens styrke og dermed for dens evne til at fremme okonomisk udvikling. "Statsstyrke" bliver da en slags mellemkommende variabel i grundopstillingens problemformulering. En stærk stat kan drive udviklingen frem, en svag stat kan næsten ingenting. Igen ser vi altså, at styringskapacitet er en afgørende variabel for præses.

En såkaldt "udviklingsstat" har først og fremmest "autonomi" i relation til genstridige grupper og klasser samt "kapacitet", hvilket især vil sige et effektivt fungerende bureaukrati til støtte for en udviklingsorienteret politisk elite. Hertil kommer så evnen til at formulere optimale politikker (også kaldet "statecraft").

Spørgsmålet er nu, om en (stærk) udviklingsstat nødvendigvis må være autoritær, som mange mener, især under henvisning til erfaringerne fra Østasien. Præses argumenterer i paperet for, at autoritære regimer ikke nødvendigvis fører til skabelse eller opretholdelse af en udviklingsstat, hvilket vi nok forstår efter at have læst hans første bog. Mere interessant er måske, at præses også 
argumenterer for, at massedominerede demokratier ofte har bedre muligheder for at skabe en stærk stat og for at fremme udvikling end autoritære regimer.

Jeg læser præses' fremstilling på den måde, at et autoritært regime hverken er en nødvendig eller tilstrækkelig betingelse for etablering eller opretholdelse af en udviklingsstat. Demokratiet har også en chance, men sikrer på den anden side ikke en udviklingsproces. Præses behøver blot at sige "ja" hertil.

Inden vi går videre, må jeg dog spørge præses, om det dominerende synspunkt i afhandlingerne taget under ét trods alt alligevel ikke er, at "bløde" autoritære regimer $\mathrm{i}$ almindelighed har bedre muligheder for at skabe økonomisk udvikling, dvs. større autonomi og kapacitet, end demokratiske systemer? Eller har vi igen problemet med "a moving target"?

\section{Centrale begreber}

I afhandlingerne anvender præses en række vigtige begreber, herunder ikke mindst demokrati. Første kapitel i Democracy, Dictatorship and Development diskuterer ret kortfattet (pp. 18-24), hvilke elementer der bør indgå i definitionen af demokrati. Præses vælger selv tre kriterier som afgørende. Kort sagt:

1) Der skal være udbredt og meningsfuld konkurrence om magtpositioner mellem individer og grupper. 2) Der skal være høj grad af deltagelse i valget af ledere og politik. 3) Der skal endelig eksistere borgerlige og politiske frihedsrettigheder, som kan sikre ovennævnte konkurrence og deltagelse.

For mig at se ligger det tredje kriterium allerede implicit i de to forste, hvis de skal have mening, men det er vel en smagssag, og under alle omstændigheder kan det ikke skade at understrege nødvendigheden af frihedsrettigheder.

Perfekte demokratier findes desværre ikke i virkelighedens verden, der kun rummer tilnærmelser til idealet. Jeg går ud fra, at præses her tænker som Robert Dahl, der ofte har sondret mellem demokrati som ideal og demokrati som faktisk forekommende styreform, der benævnes "polyarki".

Hvis demokratiets kendetegn slet ikke er til stede, har vi per definition et autoritært regime. Mellem de to yderpunkter er der imidlertid mange blandingsformer.

I Democracy and Democratization findes en mere omfattende drøftelse af demokratibegrebet. Det første kapitel hedder således "What is Democracy?" (pp. 3-24), hvilket er et stort og klassisk spørgsmål. Kapitlet bidrager imidlertid på ingen måde med nyt til den velkendte begrebsdiskussion, hvilket måske heller ikke kunne forventes i betragtning af, at bogen indgår $\mathrm{i}$ en lærebogsserie om "Dilemmas in World Politics", der sikkert har stillet visse krav til fremstillingen i forskellige henseender.

Præses fastholder i denne anden bog kort sagt sin definition af demokrati, der som nævnt lægger vægt på konkurrence, deltagelse og frihedsrettigheder. Desuden kredser han mere indgående omkring begrebet demokratisering, der angår bevægelsen fra autoritært styre mod politisk demokrati. Også her er det $\mathrm{i}$ sidste instans Robert Dahl, som er idémanden.

Men kapitlet går dog lidt længere end den første bog, idet der arbejdes videre med det tidligere nævnte synspunkt om, at demokrati i praksis ikke er et 
enten/eller, men et mere eller mindre. Konkret refereres "Freedom House's" indikatorer for demokrati i praksis, dog vist nærmest som en pligtøvelse, idet præses ikke har særlig respekt for talfæstelse af demokratiske goders værdi.

Paperet Democracy and the Developmental State rummer ikke overvejelser om demokratibegrebet som sådant. Vi står derfor alt i alt tilbage med en fornuftig mainstream afgrænsning af demokrati, der jo som flere gange antydet er det helt centrale $i$ afhandlingerne.

Et par beslægtede spørgsmål melder sig på denne baggrund. Det første går på, hvordan præses kan forsvare at tale om demokratier, der ofte eller undertiden overtræder menneskerettigheder (I: for eksempel p. 168, 187; II: for eksempel p. 86-88). Vi ved, at autokratier per definition gør det, men demokratier bør vel ikke kunne gøre det? Eller har det måske med demokrati som noget "mere eller mindre" at gøre, jf. at præses jo taler om elite- versus massedominerede demokratier (II). Hvis vi kræver, at demokratier skal sikre konkurrence, deltagelse og frihedsrettigheder, kan vi vel ikke benytte betegnelsen demokrati om systemer, der ikke lever op til kravene. Med andre ord, hvor megen elastik kan vi acceptere i omgangen med de dyre ord?

Det andet spørgsmål vedrører sammenhængen mellem begrebet demokrati og økonomisk udvikling. Jeg skal ikke gå nærmere ind i spørgsmålet om, hvordan økonomisk udvikling bedst defineres og operationaliseres. Men der er for mig at se et blødt punkt i forestillingen om økonomisk velfærd som udviklingsindikator. Problemet er, om man kan forestille sig økonomisk velfærd, dersom borgerlige og politiske rettigheder ikke samtidig er respekterede. Det gør præses vel, blandt andet under anvendelse af en række okonomiske indikatorer.

Måske er det et blot spørgsmål om aspekter og niveauer i empiriske analyser, men for mig at se er det ikke uproblematisk på individniveau at tale om økonomisk velfærd, dersom fundamentale frihedsrettigheder ikke er en del deraf. Nogle basale rettigheder må vel indgå i et begreb om økonomisk velfærd. Sat på spidsen kunne implikationen af mit synspunkt være, at autoritære regimer slet ikke kan tilvejebringe økonomisk velfærd for masserne, uanset hvor mange tabeller der kan produceres om ikke-demokratiske systemers okonomiske præstationer. I det mindste forudsætter økonomisk velfærd vel en form for retsstat, lad så være, at den ikke tillige måtte leve op til alle demokratiske krav.

\section{Metode}

Jeg vil dernæst gerne gå lidt ind på de metoder, der anvendes af præses. I bund og grund drejer det hele sig naturligvis om komparativ metode. Præses sammenligner hele tiden og undertiden sammenligner han også sammenligninger. Det foregår ovenikøbet særdeles eksplicit i den første bog (Democracy, Dictatorship and Development, pp. 34-36).

Præses har ikke megen fidus til kvantitative analyser af et stort antal lande ved hjælp af en række indikatorer. Han er heller ikke tilfreds med en dybtborende analyse af et enkelt udviklingsland. Førstnæunte er for overfladiske og usikre, sidstnævnte hæmmer generaliseringsmulighederne. Dermed er han indfanget af den komparative metodes alvorlige problematik. 
Præses vil i Democracy, Dictatorship and Development styre en vanskelig kurs mellem Scylla og Charybdis. Han vælger derfor til analyse af sin problemstilling om sammmenhængen mellem styreform og økonomisk udvikling to demokratiske og to autoritære systemer, der alle fire er stabile over tid, hvilket er en forudsætning for, at effekter af regimeforskelle kan iagttages. De to demokratiske regimer, Indien og Costa Rica, er i øvrigt meget forskellige. De to autoritære systemer, Kina og Taiwan, er også forskellige, om end knap så udpræget.

Præses benytter altså nærmest den af kloge metodikere anbefalede udvælgelsesstrategi, der kombinerer "comparable cases" i Arend Lijphart's forstand med "the most different systems" design. Præses prøver på den måde at skabe de bedst mulige betingelser for at studere regimets effekter på økonomisk udvikling. Det er flot giort, men det føles som et stort savn, at præses ikke selv $\mathrm{i}$ bogens slutning vender tilbage til dette afgerende valg af lande som studieobjekter. Kunne præses måske i dag, efter et par års tid til reflektion, kommentere et spørgsmål om, hvad han har erfaret med anvendelsen af komparativ metode i den første af afhandlingerne?

Spørgsmålet om metode er måske ikke helt så interessant i relation til den anden bog, der i det store og hele søger at sammenfatte og diskutere den meget usikre viden, der findes om demokratiets og demokratiseringers effekter i forskellige henseender. Man bemærker imidlertid, at præses, der også på denne led er et "moving target", her er trådt ud på den globale, komparative arena efter at have koncentreret sig særligt om de omtalte fire lande. Det samme kan siges om konferencepapiret. Jeg vil derfor gerne spørge præses, om han har nogle kommentarer til fordele og ulemper ved anvendelse af de forskellige metoder eller approaches, hvis han sammenligner det første arbejde med de to sidste.

\section{Resultater}

Efter denne diskussion har jeg to hovedpunkter tilbage, nemlig resultater og implikationer. Først vil jeg søge at opsummere de vigtigste substantielle hovedresultater af afhandlingerne. Det er et spørgsmål om, hvad vi har lært efter så mange timers læsning af præses' afhandlinger. Han skal nok selv få ordet, men først vil jeg nævne en række vigtige konklusioner, hvis implikationer vi siden kan diskutere.

Det afgørende spørgsmål er altså nu: Hvad ved vi i dag, som vi ikke vidste i går? Man kunne fristes til at snyde lidt med svaret ved at se på, hvad præses selv skriver om resultaterne $\mathrm{i}$ sin sammenfatning. Hvis man prøver på det, bliver man dog selv snydt, idet præses ikke gør regnskabet op på den måde, jeg her har $\mathrm{i}$ tankerne, om end han i den sammenfattende redegørelse kommenterer hver af de tre analysers resultater.

Hovedresultatet af den forste afhandling er, at der ikke findes en entydig relation mellem styreformer og økonomisk udvikling, end ikke hvis udvikling defineres blot som økonomisk vækst. Jeg har grund til at være sikker på, at præses er enig i generelle påstand, der afliver og nuancerer gængse opfattelser. 
Hovedresultatet $\mathrm{i}$ den anden bog kan ikke formuleres så enkelt, idet bogen jo, som omtalt i forbindelse med diskussionen af problemstillingerne, undersøger og bekræfter 4-5 forskellige teser. Kort sagt viser bogen, at de nye demokratier i den tredje verden er begrænsede, skrøbelige og ukonsoliderede samt plaget af alvorlige okonomiske og sociale problemer. De præges dog også af en sund folkelig mobilisering og organisering, men man skal ikke regne med at blive inddraget $i$ en ny og fredelig verdensorden. Vi skal ikke vente "a springtime of democracy" (det lyder nu ellers så smukt), men snarere frygte "a democratic decay", hvilket desværre forekommer realistisk. Dog, som antydet for snart længe siden, vi har lov at håbe, da intet er givet på forhånd. Præses forfægter ikke deterministiske synspunkter.

Endelig skal jeg minde om konferencepapirets konklusion, der gik ud på, at et autoritært regime hverken er en nødvendig eller tilstrækkelig betingelse for en udviklingsstat, idet demokratiet også har en chance.

Kan præses så nogenlunde acceptere denne superkorte sammenfatning af de vigtigste substantielle hovedresultater i de tre afhandlinger?

Da vi så nu er så nogenlunde enige om, hvad præses har fundet ud af, kan vi bevæge os til det sidste af mine hovedpunkter, nemlig en drøftelse af, hvad analyseresultaterne i grunden betyder eller implicerer i forskellige vigtige henseender. Det er et meget åbent spørgsmål, men måske også det mest spændende.

\section{Implikationer}

For at få et vist greb om en sådan diskussion, vil jeg foreslå, at vi tager udgangspunkt $i$ en sondring mellem to synsvinkler. Den ene har at gøre med faglighed eller videnskabelighed. Spørgsmålet er her: Hvad betyder disputatsen for forskningen inden for det omhandlede område, og hvad bor man som konsekvens heraf satse på at udforske i fremtiden? Man kunne sige, at denne første synsvinkel i overvejende grad er forskningspolitisk.

Den anden synsvinkel er mere politisk-politisk. Spørgsmålet er her: Hvordan kan eller bør man $i$ et overvejende politisk-ideologisk perspektiv vurdere de arbejder, præses har lagt frem til offentlig diskussion, og hvilke policyimplikationer kunne de have?

Jeg vil gerne lægge for $\mathrm{i}$ diskussionen under den første synsvinkel ved at påstå, at den del af præses' forskning, der er til behandling i dag, udgør en solid og kærkommen antidosis til lovligt optimistiske synspunkter om demokratiets fremmarch og "the end of history". Præses har leveret mange vægtige empiriske resultater og stærke argumenter, der taler for, at virkeligheden er meget mere kompliceret og fyldt med store problemer. Præses hælder vel nok mest mod et pessimistisk fremtidsbillede for den tredje verdens vedkommende og er for så vidt også på dette punkt nærmest enig med Robert Dahl, der med et andet udgangspunkt $\mathrm{i}$ bogen Democracy and its Critics når til samme resultat.

Pessimismen er formentlig velbegrundet. Men vi bør vel alligevel spørge, om det eksisterende vidensgrundlag er tilstrækkeligt. Kan vi, med andre ord, komme videre i forståelsen af sammenhængen mellem demokrati og økonomisk udvikling og af demokratiseringers muligheder $\mathrm{i}$ fremtiden, eller ved vi 
allerede, hvad vi kan få at vide? Jeg stiller altså et dobbelt spørgsmål: a) kan vi nå videre på disse områder og $\mathrm{i}$ bekræftende fald, $\mathrm{b}$ ) hvilken forskning vil da være nødvendig? Hvis præses mener, at der stadig kan gøres videnskabelige fremskridt, kunne spørgsmålet også formuleres som: Hvad ville præses gøre, hvis han fik en tilstrækkelig stor pose penge, som han selv kunne råde over til forskningsmæssige formål?

Under den anden af de synsvinkler, jeg næunte, refereres til politisk-ideologiske aspekter og policy implikationer. Her vil jeg først nævne, at præses i det første hovedarbejde (pp. 31f.) på en eksplicit måde understreger, at en personlig holdning eller bias kan farve en undersøgelse og dens resultater. Han tænker vistnok i denne forbindelse på, at de udvalgte begreber og indikatorer for demokrati og økonomisk udvikling er skabt eller inspireret af udviklingen i den forste verden af industrialiserede vestlige lande. Heri kan, siger han, ligge en form for etnocentrisme. Den tager han principielt afstand fra ved åbent og ærligt at fremhæve som sin trosbekendelse, at der findes en god, universel udviklingsproces, som tilfredsstiller individers og gruppers materielle og immaterielle behov på en måde, der ikke skader naturen.

Det kan da godt være, at de anvendte politiske og økonomiske begreber er af vestlig oprindelse, men jeg kan ikke se, at den analyse og de tolkninger, præses fremlægger i det første hovedarbejde, i særlig grad er "biased" i vestlig retning. Hertil kan selvfølgelig svares, at det nok skyldes, at jeg selv er præget af en vestlig bias. Lad andre så dømme om det. Præses forholder sig i hvert fald ikke ukritisk over for den vestlige verdens demokratiske og kapitalistiske systemer, men det gør adskillige vestlige demokratiske teoretikere just heller ikke.

Denne betragtning understøttes af, at "the moving target" i det andet hovedarbejde går nærmere ind på de forskellige demokratiopfattelser, der findes i den vestlige verden. Han fastholder af praktiske grunde en relativt snæver definition af demokrati, men det skinner tydeligt igennem, at han som så mange andre vesterlændinge principielt er tilhænger af en bredere definition, der stiller langt større krav til de sociale og økonomiske sider af demokratiske styreformer, end man sædvanligvis gør i mere snævert afgrænsede politiske definitioner af demokrati.

Jeg vil derfor konkludere, at præses ikke er biased ret meget i vestlig retning. Jeg mener tværtimod, at hans fremstillinger vidner om stor forståelse for og indleven i de problemer og særlige forhold, der gør sig gældende i den tredje verdens lande. Desuden er han klar over, at visse i snæver forstand politiske krav må stilles til ethvert demokratisk system overalt på kloden. Denne karakteristik kan præses vel ikke tænke sig at anfægte?

Herefter er der spørgsmålet om analysernes mulige policy implikationer. Som udgangspunkt for diskussionen har vi dels hovedresultaterne, dels præses' synspunkter om et ideelt set bredt favnende demokrati. Spørgsmålet kan koges ind til følgende: Hvad kan vestlige donorlande, inklusive Danmark med DANIDA som udførende led, lære af præses med henblik på den udviklingsbistandspolitik, der bør føres i relation til den tredje verden? 
Jeg forudsætter naturligvis, at de rige lande bør støtte udviklingslandene med begrundelser, der i varierende grad kan rumme elementer af idealisme, altruisme og egoisme. Den bistandspolitik, der i de seneste år er ført af adskillige demokratiske donorlande, inklusive Danmark, indeholder som noget relativt nyt et krav til støttemodtagende lande om at fremme demokrati og at sikre menneskerettigheder. Denne betingelse for hjælp må præses principielt være tilhænger af. Han ved imidlertid også, at indførelse af politisk demokrati ikke nødvendigvis fører til økonomisk udvikling, og at demokratiseringsprocessen ikke er irreversibel. På den anden side har demokratiet en egenværdi. Man kunne måske sige, at demokrati plus dårlig økonomi trods alt er bedre end diktatur plus dårlig økonomi.

Robert Dahl sluttede i 1989 (Democracy and its Critics, p. 317) sine overvejelser på dette punkt ved at sige:

\footnotetext{
"The capacity of democratic countries to bring about democracy in other countries will remain rather limited. Yet, democratic countries could aid democratization of nondemocratic countries by steadily pursuing policies over many years that focus on changes in the underlying conditions that support stable polyarchy."
}

Det synes at fremgå, især af slutkapitlet i det andet hovedarbejde og af konferencepapiret, at præses tænker i lignende baner. I hvert fald fremhæver han vigtigheden af, at de nye demokratier får en solid massebasis. Det er ikke gjort med at støtte begrænsede, elitedominerede demokratier. Har jeg ret i det, eller stiller præses yderligere krav til en god demokratisk udviklingspolitik?

Jeg benyttede to synsvinkler i denne diskussion om resultaternes implikationer. Måske er den anvendte sondring lidt kunstig i praksis, selv om den analytisk set giver god mening. Jeg vil derfor afslutningsvis indføre en tredje synsvinkel, der på den ene side peger på et vanskeligt problem og på den ande side bygger en slags bro mellem de to førstnæunte, der lægger vægt på henholdsvis videnskabelig erkendelse og policy rekommandationer.

Denne tredje synsvinkel fokuserer på det intrikate spørgsmål om, hvad en forskers egen rolle børe være i det store problemkompleks om "demokrati og udvikling". En række spørgsmål melder sig her:

- Bør den indsigtsfulde forsker, der hylder demokrati som styreform, lade sig ansætte af Danida som fødselshjælper for demokrati i den tredje verden?

- Eller bør han/hun snarere fortsætte med via uafhængig forskning at skabe viden, hvoraf gode råd kan udledes?

- Eller bør den indsigtsfulde og engarerede forsker måske kunne skifte mellem rollerne, således at han/hun for eksempel er videnskabs-mand/kvinde $\mathrm{i}$ forårssemestret og ikke helt så fri Danida-konsulent om efteråret?

Med disse spørgsmål forsøger jeg at antyde en vigtig problematik, der ret beset er højaktuel for mange andre end udviklingsforskere. Den rummer personlige, moralske overvejelser for den enkelte forsker såvel som meget vigtige universitetspolitiske perspektiver: Forskning på universiteter bør principielt være fri og ubundet af andet end hensynet til erkendelse, men da også gerne til nytte for samfundet og sågar hele den tredje verden. 
Jeg ser mange dilemmaer, konfliktmuligheder og svære valg i denne forbindelse. Mit allersidste spørgsmål er: Hvordan stiller præses sig i diskussionen om forskerens personlige rolle, når det gælder at fremme en ønskelig udvikling på et demokratisk grundlag?

\section{Afsluttende bemærkninger}

Jeg har koncentreret mig om en række teoretiske og substantielle aspekter af de indleverede tre arbejder, da jeg jo hverken er korrekturlæser eller manuskriptredaktør. Alligevel vil jeg gerne fremhæve et par mere formelle sider af afhandlingerne.

Præses skal roses for en levende og undertiden endog smuk sprogbrug. Han er som regel klar og koncis og bruger ikke flere ord og mere papir end nødvendigt. I det forste store arbejde, der er gennemført med en imponerende selvdisciplin, afslører han ganske vist en overdreven hang til mange og lange citater, men også i den henseende viser han sig heldigvis at være "a moving target".

Til syvende og sidst er det dog indholdet, det drejer sig om. Jeg og andre har i dag fremført en lang række spørgsmål til drøftelse, herunder en del af nok så kritisk art. Det er min opfattelse, at præses har svaret godt for sig, hvilket bekræfter min forhåndsopfattelse af, at de indleverede arbejder, som det hedder $\mathrm{i}$ bekendtgørelsen om doktorgraden, "har bragt videnskaben et væsentligt skridt videre". 